\title{
The evaluation of oxidative stress parameters in the benign prostatic hyperplasia, prostatitis and prostate cancer
}

\section{Benign prostat hiperplazisi, prostatit ve prostat kanserinde oksidatif stres parametrelerinin değerlendirilmesi}

\author{
Aliseydi Bozkurt ${ }^{*}$ (D), Cebrail Gürsul ${ }^{2}$ (D), Merve Aydin ${ }^{3}$ (D), Illyas Sayar ${ }^{4}$ (D), Mehmet Karabakan ${ }^{1}$ (D), \\ Aytekin Çikman ${ }^{3}$ \\ ${ }^{1}$ Erzincan University, Faculty of Medicine, Department of Urology, Erzincan, Turkey \\ ${ }^{2}$ Erzincan University, Faculty of Medicine, Department of Physiology, Erzincan, Turkey \\ ${ }^{3}$ Erzincan University, Faculty of Medicine, Department of Microbiology, Erzincan, Turkey \\ ${ }^{4}$ Erzincan University, Faculty of Medicine, Department of Pathology, Erzincan, Turkey \\ * Corresponding author: Aliseydi Bozkurt E-mail: draliseydi@gmail.com ORCID: 0000-0003-3367-8523 \\ Received: 21 September 2018 Accepted: 8 November 2018
}

\begin{abstract}
Aim: Recently, oxidative stress has been well known that it has especially important a role in benign prostatic hyperplasia, prostatitis, and prostate cancer. The present study has planned to estimate parameters of the oxidative stress and the antioxidant status in patients with benign prostatic hyperplasia, prostatitis and prostate cancer.

Material and Method: For this aim totally fourty men with benign prostatic hyperplasia $(n=14)$, prostatitis $(n=15)$ and prostate cancer $(n=11)$ without any other chronic disease, and who not use cigarettes and alcohol were subjected. Venous blood samples were taken. Thiobarbituric acid reaction (TBARS), total oxidant status (TOS), total antioxidant capacity (TAC), glutathione (GSH) levels, and catalase (CAT) activity in serum were assessed in patient with prostatitis, and prostate cancer compared to benign prostatic hyperplasia.

Results: It was viewed that GSH levels were significantly lower, TBARS and TOS levels were significantly higher in patients with of prostate cancer compared to benign prostatic hyperplasia. Also, GSH and CAT significant different was determined in prostatitis compared to BPH. Oxidative stress may be concluded in prostate cancer and prostatitis, proved via the higher TBARS levels and lower GSH levels.
\end{abstract}

Conclusion: The increased activity of antioxidant enzyme may be a compensatory regulation in response to oxidative stress.

Keywords: benign prostatic hyperplasia, prostatitis, prostate cancer, oxidative stress

( 2019 by the authors; licensee MEDITAGEM Ltd., Turkey. This article is an open access article distributed under the terms and conditions of the Creative Commons Attribution License (http://creativecommons.org/licenses/by/4.0/). 


\section{ÖZ}

Amaç: Son zamanlarda, oksidatif stresin iyi huylu prostat hiperplazisi, prostatit ve prostat kanserinde özellikle önemli bir rolü olduğu iyi bilinmektedir. Bu çalışma benign prostat hiperplazisi, prostatit ve prostat kanseri olan hastalarda oksidatif stres ve antioksidan parametreleri değerlendirmeyi planlamaktadır.

Gereç ve Yöntem: Bu amaçla benign prostat hiperplazisi $(n=14)$, prostatit $(n=15)$ ve prostat kanseri $(n=11)$ diğer kronik hastalığı olmayan, sigara ve alkol kullanmayan toplamda kırk erkek hasta değerlendirmeye alındı. Venöz kan örnekleri alındı. Prostatit ve prostat kanserli hastalarda tirobarbitürik asit reaksiyonu (TBARS), total oksidan durum (TOS), total antioksidan kapasite (TAC), glutatyon (GSH) düzeyleri ve katalaz (CAT) aktivitesi iyi huylu prostat hiperplazisine göre değerlendirildi.

Bulgular: GSH düzeylerinin anlamlı derecede düşük olduğu, TBARS ve TOS düzeylerinin benign prostat hiperplazisine göre prostat kanserli hastalarda anlamlı olarak daha yüksek olduğu görülmüştür. Ayrıca, GSH ve CAT, BPH ile karşılaştırıldığında prostatitde önemli ölçüde farklı bulunmuştur. Oksidatif stres, daha yüksek TBARS seviyeleri ve daha düşük GSH seviyeleri ile prostat kanseri ve prostatit de görülebilir.

Sonuç: Antioksidan enzimin artan aktivitesi, oksidatif strese yanıt olarak telafi edici bir düzenleme olabilir.

Anahtar kelimeler: benign prostat hiperplazisi, prostatit, prostat kanseri, oksidatif stres

\section{INTRODUCTION}

Benign prostatic hyperplasia (BPH) is one of the most known urological diseases in aging men. It often progresses after the 40 age and ranges in prevalence from too $50 \%$ at 60 age to as high as $90 \%$ after 85 age [1]. BPH is defined as has high morbidity and low mortality rate, and is acceptable as a public health problem [2]. Prostate cancer (PCa) is one of the most frequently diagnosed malignancies in men [3]. The mechanism of prostate carcinogenesis is not entirely understood, but proof suggests that oxidative stress plays a role [4]. The correlation between risk of prostate cancer and oxidative stress has been well-known. There is remarkable proof defining oxidative stress conduces to pathogenesis and etiology of the prostate cancer $[5,6]$. Epidemiological research at the last years shows "prostatitis" to be one of the major medical healthcare problems in urology [7]. Recently, oxidative stress has been defined in patients with prostatitis and it is well adopted that areas of prostatic inflammation can produce free radicals, such as nitric oxide and many derived-oxygen radicals [8,9]. Chronic inflammation can initiate proliferative events and on the DNA modifications in prostate tissue by the oxidative stress. The reality in fact, recurred tissue damage and oxidative stress connected with this event may incite a compensative cellular proliferation with the risk of hyperplasia growth or neoplasm [8]. It is adopted that areas of prostate inflammation compose free radicals and many radicals derived oxygen. In particular, macrophages and infiltration of neutrophil supply an important origin of free radicals that can induce hyperplasia or precancerous transformations through the oxidative stress to the tissue and DNA [10]. Reactive oxygen species (ROS) increase the risk for DNA damage and inhibition of DNA repair in tumor cells [11]. Increased ROS production has conventionally been associated with tissue or DNA damage. But new and thrilling knowledge points to a main role for its increased production in different cellular processes connected with neoplastic transformation and abnormal growth and proliferation [12]. Moreover, ROS is the basis of many disease such as inflammatory diseases, neurodegenerative diseases, atherosclerosis, cancer and so on [13]. The human body is constantly exposed to the attack of free radicals. In the origin of the numerous diseases, inclusive tumors, known as increased in production of ROS resulting with oxidative stress. Level of prostatic hyperplasia and growth are frequently accompanied with inflammation initiated by improved production of ROS, oxidizing halogen derivatives, and reactive nitrogen species [14]. Increased amount of the ROS cause to damage of the biological structures [15]. DNA damage may seriatim reason to modifications in transcription and replication, initiation of signal transmission pathways, and genomic instability, which forms the basis for carcinogenesis [16]. Alive organism is protected against the detrimental ROS activity through a quite complex antioxidant system. Enzymatic antioxidants turbot contains, within other component, superoxide dismutase (SOD), which catalyses superoxide anion dismutation, as well as catalase (CAT) and glutathione peroxidase, as dissociate hydrogen peroxide $[17,18]$.

In the previous studies have defined the changed oxidantantioxidant status in semen, serum, plasma, and the 
prostatic tissue of human and rats, or in persistent cell lines [19-22]. In this way, massive generation of ROS and/or deficiency in antioxidant defense system of the healthy cells can result with oxidative stress and the increased of ROS may play an important role in cellular processes associated with induction and improving of prostate inflammation, $\mathrm{BPH}$, and numerous cancer species involving PCa. The present study was conceived to detect the oxidative stress markers and antioxidant status such as TBARS, TAC, TOS, GSH levels, CAT activity in patients with $\mathrm{BPH}$, prostatitis, and PCa.

\section{MATERIAL AND METHOD}

\section{Patients and Blood Samples}

This study was included between 55-70 aged patients with $\mathrm{BPH}$, prostatitis, and PCa without any other chronic disease and who not use cigarettes and alcohol, diagnosed at the Clinic of Urology, Faculty of Medicine, Erzincan University, Erzincan, Turkey. Also, Patients with medical conditions that alter oxidative status, such as another malignant disease, active inflammatory disease, thyroid disease, ischemic disease, diabetes mellitus, vascular disease, and severe dysfunction of the kidney, liver or heart were excluded from study. A complete medical history and physical examination were provided by all study participants. The study was authorized by Health Science Human Researches Ethical Committee of Erzincan University (No. 5/1-29.11.2013). Benign prostatic hyperplasia, prostatitis, and prostate cancer were divided into 3 groups. Group 1(BPH): this group was created patients diagnosed with BPH. Group 2 (prostatitis): this group was conducted patients diagnosed with prostatitis. Group 3 (PCa): this group was composed patients diagnosed with PCa. Blood samples were obtained after fasting 12 hour period. Samples were withdrawn from an antecubital vein into blood tubes and immediately stored in ice at $4{ }^{\circ} \mathrm{C}$. Serum was separated from the blood after allowing it to stay in a test tube for about 30 minutes, followed by centrifugation at $3000 \mathrm{rpm}$ for 10 minutes and stored at $-20^{\circ} \mathrm{C}$ until used for the ELISA assays.

\section{Biochemical Analysis}

\section{ELISA assays}

Serum CAT activity, GSH and TBARS levels were quantified by using an ELISA kit (Cayman Chemical Company, Michigan, USA). TOS and TAC levels were quantified by using an ELISA kit (Real Assay Diagnostics, Gaziantep, Turkey). All assay procedures were carried out according to the manufacturer's instructions. The absorbance of standards and samples were obtained at $450 \mathrm{~nm}$ wavelength using an
Table 1. The mean \pm SD values of Total antioxidant capacity (TAC), Total oxidant status (TOS), Glutathione (GSH), Thiobarbituric acid reaction (TBARS), and Catalase (CAT) in patients with $\mathrm{BPH}$, Prostatitis, and PCa

\begin{tabular}{|c|c|c|c|c|c|}
\hline & $\begin{array}{c}\text { TAC } \\
(\mathrm{mmol} / \mathrm{l})\end{array}$ & $\begin{array}{c}\text { TOS } \\
(\mu \mathrm{mol} / \mathrm{l})\end{array}$ & $\begin{array}{c}\text { CAT } \\
(\mathrm{nmol} / \\
\mathrm{min} / \mathrm{ml})\end{array}$ & $\begin{array}{c}\text { GSH } \\
(\mathrm{nmol} / \mathrm{ml})\end{array}$ & $\begin{array}{c}\text { TBARS } \\
(\mathrm{nmol} / \mathrm{ml})\end{array}$ \\
\hline $\begin{array}{c}\text { BPH } \\
(\mathbf{n = 1 4 )}\end{array}$ & $1.62 \pm 0.25$ & $8.78 \pm 3.73$ & $\begin{array}{c}51.41 \pm \\
22.44\end{array}$ & $5.29 \pm 1.36$ & $2.10 \pm 0.68$ \\
\hline $\begin{array}{c}\text { Prostatitis } \\
\text { (n=15) }\end{array}$ & $1.49 \pm 0.32$ & $9.79 \pm 3.23$ & $\begin{array}{c}45.26 \pm \\
20.95\end{array}$ & $5.24 \pm 1.54$ & $2.66 \pm 0.84$ \\
\hline $\begin{array}{c}\text { PCa } \\
(\mathbf{n = 1 1 )}\end{array}$ & $1.32 \pm 0.34$ & $\begin{array}{c}11.73 \pm \\
2.76\end{array}$ & $\begin{array}{c}39.14 \pm \\
23.96\end{array}$ & $3.96 \pm 1.22$ & $2.93 \pm 1.1$ \\
\hline
\end{tabular}

Epoch spectrophotometer (Biotech Instruments, Inc., Winooski, VT, USA). A standard curve was plotted with standard concentration on the $x$-axis and absorbance on the $y$-axis to determine levels of CAT $(\mathrm{nmol} / \mathrm{min} / \mathrm{ml}), \mathrm{GSH}$ $(\mathrm{nmol} / \mathrm{ml})$, TBARS $(\mathrm{nmol} / \mathrm{ml})$, TOS $(\mu \mathrm{mol} / \mathrm{l})$ and TAC $(\mathrm{mmol} / \mathrm{l})$.

\section{Statistical Analysis}

The results are presented as the mean \pm S.D. Normality test (Shapiro Wilk and Levene test) to assay the homogeneity of variance for variables were evaluated. While data were analysed, previously the one-way analysis test was made for comparison of three more group and later BonferroniDunn's test of Kruskal-Wallis from multiple comparison test was used in the situation that Tukey HSD test from the multiple comparison tests were not provided. The significance level was shown as $p<0.05$. SPSS 20 for data analysis (Released 2011. IBM Corp. IBM SPSS Statistics for Windows, Version 20.0. Armonk, NY: IBM Corp.) Statistical package program was used.

\section{RESULTS}

It has been focused on the importance of free radical damage in the determined of $\mathrm{BPH}$, prostatis, and PCa. Besides, it has been intensely worked to prevent its initiation or progression. Also, recently in several preclinic and clinic studies have been demonstrated that therapies supporting antioxidant system have been made to decrease and minimize development of the $\mathrm{BPH}$, prostatitis, and $\mathrm{PCa}$. The mean \pm SD of serum TAC, TOS, TBARS, CAT, and GSH are indicated in Table 1. There was a statistically significant for the GSH levels between PCa with BPH and Prostatitis with $\mathrm{BPH}$. The TAC levels were significantly higher in Prostatitis and $\mathrm{PCa}$ group compared to group $\mathrm{BPH}(\mathrm{P}<0.05$; Figure 1). The levels of plasma CAT showed significant different between $\mathrm{BPH}$ and Prostatitis $(\mathrm{P}<0.05$; Figure 1). In the present study GSH an antioxidant was significantly lower in patients with $\mathrm{PCa}$ compared to Prostatitis and $\mathrm{BPH}(\mathrm{P}<0.05$; 


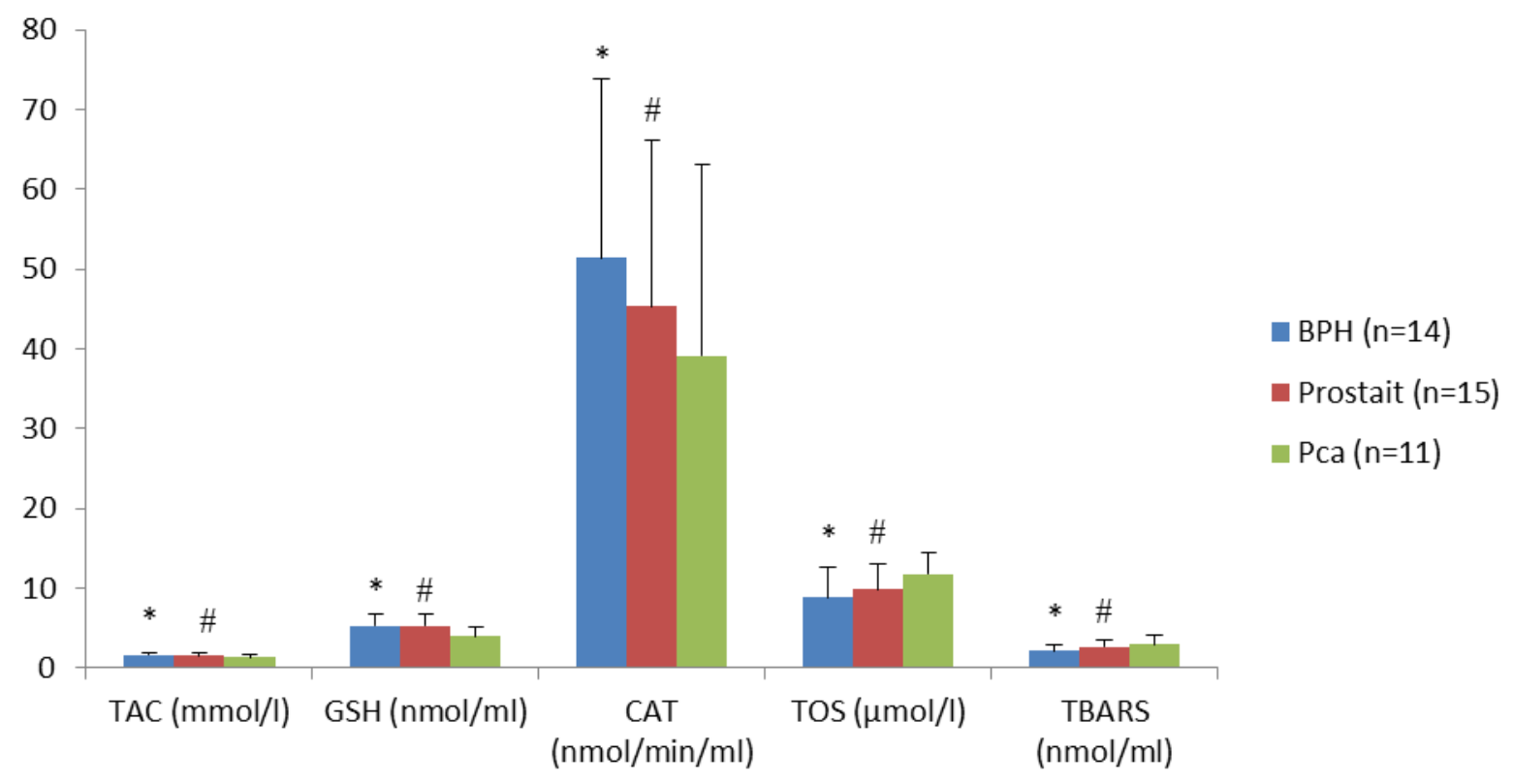

Figure 1. Statistically significant values of Total antioxidant capacity (TAC), Total oxidant status (TOS), Glutathione (GSH), Thiobarbituric acid reaction (TBARS), and Catalase (CAT) in patients with BPH, Prostatitis, and PCa

*: Compered to between the prostatitis and BPH $(p<0.05)$

\#: Compered to between the BPH and PCa $(p<0.05)$

Figure 1). TBARS levels more increased in PCa group compared to $\mathrm{BPH}$ and in Prostatitis compared to $\mathrm{BPH}$ $(P<0.05$; Figure 1). TOS level was improved, as a biomarker of the oxidative stress, in PCa and Prostatitis. This situation was lower in group of patients with $\mathrm{BPH}$ as seen in the Table 1 and Figure 1.

\section{DISCUSSION}

$\mathrm{BPH}$ is the most often benign neoplasm for men as an endocrine disorder. Significant majority men will be treated in their lifetimes related to the symptoms of BPH [23]. PCa is disease of the male above the age of 50 years worldwide [24]. The numerous people endure with prostatitis which is one of the most prevalent problems in urinary and andriatry surgery/therapy [25]. In fact we can say that in these three diseases importantly is associated with oxidative stress. Oxidative stress is one of the results unavoidable in the aerobic life. Gradually increasing evidences show that the accumulation and generation of the ROS and reactive nitrogen species play a main role in the aging process and age-related various diseases such as prostate cancer [26,27]. These extremely reactive oxidant molecules have connected and oxidation of lipid, DNA, and proteins, also they reacts with neighborhood structures. When the oxidative damage is not repaired that can cause mutations, increasing the risk of carcinogenesis [28]. ROS are related to dissimilar grades of carcinogenesis, through either immunological mechanisms or DNA damage, as interact coaction with tumor suppressor genes, oncogenes [29]. Furthermore, ROS may also lead to the generation of DNA adducts indirectly by starting autocatalytic lipid peroxidation, which creates a great range of potentially genotoxic breakdown products, containing aldehyde and lipid proxyl radicals (ROO), such as malondialdehyde [30,31]. Consequently, the DNA is intensely oxidatively modified and damaged [32,33]. The oxidative hydroxylation causes a lack of base with quite mutagenic lesion of nuclear DNA, that it is resulted with faulty reading of the modified base and adjacent residues. When any oxidative lesion is not repaired can results mutations, increasing the risk of carcinogenesis [28,34-37]. Moreover, oxidative damage are tightly associated with chronic prostatitis [38]. Also, the grade of oxidative damage induced by ROS can be intensified due to derogation in the performance of antioxidant defense system. This defense systems against the ROS involve antioxidant enzymes such as: glutathione peroxidase, catalase, and superoxide dismutase [39]. In previous various human and animal studies have been evaluated some parameters of oxidative stress in patients with benign prostatic hyperplasia, prostatitis, and prostate cancer. For example Sarafinovska et al., reported that antioxidant enzyme activities decreased and oxidative stress parameters increased in prostate cancer [4].

When balance of ROS-antioxidant in prostatic tissue is destroyed, the activities of prostatic antioxidant enzymes (such as SOD, CAT and GPx) are obviously decreased while the level of TBARS is significantly improved [40]. It has been 
reported that the activities of SOD, CAT and GPx are increased by the treatment of antioxidant for 4 weeks obviously, and decreased the level of TBARS in prostate tissue compared to carrageenan-induced bacterial prostatitis group [41]. It has been well known lead to DNA damage of the ROS but also, these products are extremely make prone to the malignant transformation from the prostate hyperplasia [42,43]. In previous a study, it has been determined that levels of antioxidants in blood of patients with PCa was reduced [44] and increased of markers lipid peroxidation [44,45]. Adedapo et al.'s in study, TAC level higher in patients with PCa compare to the BPH [46]. In a study that comparison of semen characteristics and measures of oxidative stress between healthy men (control) and patients with chronic prostatitis, TAC was higher in patients with chronic prostatitis according to the control group [21]. In the other study, in patients with chronic bacterial prostatitis compared to healthy men volunteers erythrocyte malondialdehyde levels increased and erythrocyte SOD, CAT and GPx activities significantly decreased [40]. Our study has been demonstrated that TBARS, as an indicator of lipid peroxidation level, increased. TAC and CAT decreased, as specifier of antioxidant enzymes in the blood of patients with BPH is a disease nearly related to oxidative stress. But severity of oxidative tissue damage more increased in group of the patients with Prostatitis and PCa due to TBARS levels much more improved. Fundamentally increased lipid peroxidation can be devastating to different tissues if not scavenged by antioxidant defense system as a consequence of overwhelming free radicals. Consequently, the serum antioxidant enzymes might be used to set against the rised lipid peroxidation in the tumor or inflammation-affected tissue. Another speculation is that the increased lipid peroxidation consists as conclusion of the inadequate force of consumed antioxidant defense system for a prolonged time. Additionally, in group of the patients with Prostatitis and PCa dropped significantly CAT activity, TAC, and GSH levels. In the light of literature and our own findings we can say that the CAT activity, TAC, and GSH levels may possibly decreased to detoxify substantially of the hydrogen peroxide. Because these antioxidant enzymes may be used in the start and continue of defense against the raised lipid peroxidation in the touched tissue [47].

The results in this study suggest that there exist increased oxidative stress as more severe and damage in patients with chronic bacterial prostatitis and prostate cancer according to patients with $\mathrm{BPH}$.

\section{ACKNOWLEDGEMENTS}

The authors are grateful to Erzincan University, Urology Clinic and to volunteers participating in our study.

\section{DECLARATION OF CONFLICT OF INTEREST}

The authors declare no conflict of interest associated with this manuscript.

\section{REFERENCES}

1. (AUA) AUA. AUA guideline on management of benign prostatic hyperplasia. Diagnosis and treatment recommendations. AUA Practice Guidelines Committee. J Urol. 2003; 170: 530-47.

2. Pagano E, Laudato M, Griffo M, Capasso R. Phytotherapy of Benign Prostatic Hyperplasia. A Minireview. Phytother Res. 2014; 28: 949-55.

3. Murphy L, Watson RW. Patented prostate cancer biomarkers. Nat Rev Urol. 2012; 9: 464-72.

4. Arsova-Sarafinovska Z, Eken A, Matevska N, et al. Increased oxidative/nitrosative stress and decreased antioxidant enzyme activities in prostate cancer. Clin Biochem 2009; 42: 1228-35.

5. Chomyn A, Attardi G. MtDNA mutations in aging and apoptosis. Biochem Bioph Res Co 2003; 304: 519-29.

6. Dakubo GD, Parr RL, Costello LC, Franklin RB, Thayer RE. Altered metabolism and mitochondrial genome in prostate cancer. J Clin Pathol 2006; 59: 10-6.

7. Motrich RD, Maccioni M, Molina R, et al. Presence of INF gamma-secreting lymphocytes specific to prostate antigens in a group of chronic prostatitis patients. Clin Immunol. 2005; 116: 149-57.

8. Palapattu GS, Sutcliffe S, Bastian PJ, et al. Prostate carcinogenesis and inflammation: emerging insights. Carcinogenesis. 2005; 26: 1170-81.

9. Turk S, Kullisaar T. Are prostatitis symptoms associated with an isoprostane-mediated vicious circle? Med Hypotheses. 2011; 77: 837-40.

10. Sciarra A, Di Silverio F, Salciccia S, Gomez AMA, Gentilucci A, Gentile V. Inflammation and chronic prostatic diseases: Evidence for a link? Eur Urol. 2007; 52: 964-72. 
11. de Miguel MP, Royuela M, Bethencourt FR, Santamaria $L$, Fraile B, Paniagua R. Immunoexpression of tumour necrosis factor-alpha and its receptors 1 and 2 correlates with proliferation/apoptosis equilibrium in normal, hyperplasic and carcinomatous human prostate. Cytokine. 2000; 12: 535-8.

12. Naka K, Muraguchi T, Hoshii T, Hirao A. Regulation of reactive oxygen species and genomic stability in hematopoietic stem cells. Antioxid Redox Sign. 2008; 10: 1883-94.

13. Kalra N, Prasad S, Shukla Y. Antioxidant potential of black tea against 7,12-dimethylbenz(a)anthracene-induced oxidative stress in Swiss albino mice. J Environ Pathol Tox. 2005; 24: 105-14.

14. Damber JE, Aus G. Prostate cancer. Lancet. 2008; 371: 1710-21.

15. Jomova K, Valko M. Advances in metal-induced oxidative stress and human disease. Toxicology. 2011; 283: 65-87.

16. Seifried HE, Anderson DE, Fisher El, Milner JA. A review of the interaction among dietary antioxidants and reactive oxygen species. J Nutr Biochem. 2007; 18: 567-79.

17. Elahi MM, Kong YX, Matata BM. Oxidative stress as a mediator of cardiovascular disease. Oxid Med Cell Longev. 2009; 2: 259-69.

18. Griendling KK, Sorescu D, Lassegue B, Ushio-Fukai M. Modulation of protein kinase activity and gene expression by reactive oxygen species and their role in vascular physiology and pathophysiology. Arterioscl Throm Vas. 2000; 20: 2175-83.

19. Jung K, Seidel B, Rudolph B, et al. Antioxidant enzymes in malignant prostate cell lines and in primary cultured prostatic cells. Free Radical Bio Med. 1997; 23: 127-33.

20. Murray Gl, Taylor VE, Mckay JA, et al. The Immunohistochemical Localization of DrugMetabolizing-Enzymes in Prostate-Cancer. J Pathol. 1995; 177: 147-52.

21. Pasqualotto FF, Sharma RK, Potts JM, Nelson DR, Thomas AJ, Agarwal A. Seminal oxidative stress in patients with chronic prostatitis. Urology. 2000; 55: 881-5.

22. Yamazaki H, Schneider E, Myers CE, Sinha BK. Oncogene Overexpression and De-Novo Drug-Resistance in Human Prostate-Cancer Cells. Bba-Mol Basis Dis. 1994; 1226: 8996.
23. Mebust WK, Holtgrewe HL, Cockett ATK, Peters PC, Comm W. Transurethral prostatectomy: Immediate and postoperative complications. Cooperative study of 13 participating institutions evaluating 3,885 patients. J Urology. 2002; 167: 5-9.

24. Ogunbiyi JO, Shittu OB. Increased incidence of prostate cancer in Nigerians. J Natl Med Assoc. 1999; 91: 159-64.

25. Wilson MJ, Woodson M, Wiehr C, Reddy A, Sinha AA. Matrix metalloproteinases in the pathogenesis of estradiol-induced nonbacterial prostatitis in the lateral prostate lobe of the Wistar rat. Exp Mol Pathol. 2004; 77: 7-17.

26. Cooke MS, Evans MD, Dizdaroglu M, Lunec J. Oxidative DNA damage: mechanisms, mutation, and disease. Faseb J. 2003; 17: 1195-214.

27. DeWeese TL, Hruszkewycz AW, Marnett LJ. Oxidative stress in chemoprevention trials. Urology 2001; 57: 13740.

28. Cooke MS, Evans MD, Herbert KE, Lunec J. Urinary 8-oxo2 '-deoxyguanosine - Source, significance and supplements. Free Radical Res. 2000; 32: 381-97.

29. Kang DH. Oxidative stress, DNA damage, and breast cancer. AACN Clin Issues 2002; 13: 540-9.

30. Dotan Y, Lichtenberg D, Pinchuk I. Lipid peroxidation cannot be used as a universal criterion of oxidative stress. Prog Lipid Res 2004; 43: 200-27.

31. Meagher EA, Fitzgerald GA. Indices of lipid peroxidation in vivo: Strengths and limitations. Free Radical Bio Med 2000; 28: 1745-50.

32. Valko M, Izakovic M, Mazur M, Rhodes CJ, Telser J. Role of oxygen radicals in DNA damage and cancer incidence. Mol Cell Biochem 2004; 266: 37-56.

33. Valko M, Rhodes CJ, Moncol J, Izakovic M, Mazur M. Free radicals, metals and antioxidants in oxidative stressinduced cancer. Chem-Biol Interact 2006; 160: 1-40.

34. Chiou CC, Chang PY, Chan EC, Wu TL, Tsao KC, Wu JT. Urinary 8-hydroxydeoxyguano sine and its analogs as DNA marker of oxidative stress: development of an ELISA and measurement in both bladder and prostate cancers. Clin Chim Acta 2003; 334: 87-94. 
35. Foksinski M, Kotzbach R, Szymanski W, Olinski R. The level of typical biomarker of oxidative stress 8-hydroxy-2 'deoxyguanosine is higher in uterine myomas than in control tissues and correlates with the size of the tumor. Free Radical Bio Med 2000; 29: 597-601.

36. Poulsen $\mathrm{HE}$, Prieme $\mathrm{H}$, Loft $\mathrm{S}$. Role of oxidative DNA damage in cancer initiation and promotion. Eur J Cancer Prev 1998; 7: 9-16.

37. Wu LL, Chiou CC, Chang PY, Wu JT. Urinary 8-OHdG: a marker of oxidative stress to DNA and a risk factor for cancer, atherosclerosis and diabetics. Clin Chim Acta 2004; 339: 1-9.

38. Volchegorskii IA, Tarasov NI, Seregin SP. The role of freeradical lipid oxidation in the pathogenesis of chronic prostatitis. Urologiiâ Nefrologiiâ 1997; 5: 24-5

39. Conklin KA. Dietary antioxidants during cancer chemotherapy: Impact on chemotherapeutic effectiveness and development of side effects. Nutr Cancer 2000; 37: 1-18.

40. Zhou JF, Xiao WQ, Zheng YC, Dong J, Zhang SM. Increased oxidative stress and oxidative damage associated with chronic bacterial prostatitis. Asian J Androl 2006; 8: 317-23.
41. Lei YF, Ren XH, Chen JL, Liu D, Ruan JL. Protective effects of grape seed-derived procyanidin extract against carrageenan-induced abacterial prostatitis in rats. J Funct Foods 2014; 7: 416-24.

42. De Marzo AM, Nakai Y, Nelson WG. Inflammation, atrophy, and prostate carcinogenesis. Urol Oncol-Semin Ori 2007; 25: 398-400.

43. Hallstrom TMKA, Laiho M. Genetic changes and DNA damage responses in the prostate. Prostate. 2008; 68: 902-18.

44. Akinloye O, Adaramoye O, Kareem O. Changes in antioxidant status and lipid peroxidation in Nigerian patients with prostate carcinoma. Pol Arch Med Wewn 2009; 119: 526-31.

45. Aydin A, Arsova-Sarafinovska Z, Sayal A, et al. Oxidative stress and antioxidant status in non-metastatic prostate cancer and benign prostatic hyperplasia. Clin Biochem 2006; 39: 176-9.

46. Adedapo KS, Arinola OG, Shittu OB, Kareem OI, Okolo CA, Nwobi LN. Diagnostic value of lipids, total antioxidants, and trace metals in benign prostate hyperplasia and prostate cancer. Niger J Clin Pract 2012; 15: 293-7.

47. Barker AM, Oberley LW, Cohen MB. Expression of antioxidant enzymes in human prostate adenocarcinoma. Prostate Cancer P D. 1997; 32: 229-33. 